\title{
Temporal and spatial distribution of bovine tuberculosis outbreaks in Turkey (2005-2020)
}

\author{
Şahin Çakır ${ }^{1}$ (), Mustafa Yakar² (), Fevziye İpek Keskin³ (-) \\ ${ }^{1}$ Ministry of Agriculture and Forestry, General Directorate of Agricultural Research and Policies, Department of Animal Health, \\ Food and Feed Research, Ankara, Turkey. \\ ${ }^{2}$ Süleyman Demirel University, Faculty of Arts and Sciences, Department of Geography, Isparta, Turkey. \\ ${ }^{3}$ Ministry of Agriculture and Forestry, General Directorate of Food and Control, Veterinary Control Central Research Institute, \\ Ankara, Turkey.
}

Geliş Tarihi / Received: 17.09.2021, Kabul Tarihi / Accepted: 15.11.2021

\begin{abstract}
This research aims to reveal the temporal changes and spatial patterns of Bovine Tuberculosis (bTB) in Turkey in the last 16 years using OIE and MoAF data. Considering the zoonotic character and socio-economic impact of the disease, the rapid increase in the number of bTB outbreaks has reached alarming levels recently. As a matter of fact, around 20-fold increase in the number of outbreaks between 2005 and 2020 clearly shows this. In the same period, the compensation payment of approximately 611 million new TL ( $€$ ) for 168,244 cattle that were conditionally slaughtered and died due to illness reveals the economic impact of the disease. Also, it is known that human cases are caused by M. bovis, although at a low rate (5.3\%). In parallel with the increase in the number of bTB outbreaks, it has spread throughout the country (except for some provinces) geographically. It is important to fight bTB disease effectively, to reduce the risks to public health and the socio-economic losses caused by the disease. For this reason, it is extremely important to monitor the temporal course of the disease outbreaks epidemiologically and to reveal their spatial patterns at various scales. For an effective fight against bTB, it is vital to monitor, analyze, and put into practice the temporal changes and spatial distribution dynamics of all the variables (especially animal movements) of the transmission dynamics in the epidemiology of the disease.
\end{abstract}

Keywords: Bovine tuberculosis, Mycobacterium bovis, spatial distribution, temporal distribution, zoonosis

\section{Türkiye'de sığır tüberkülozu mihraklarının zamansal ve mekânsal dağılımı (2005-2020)}

\begin{abstract}
Özet: Bu araştırma, OIE ve Tarım ve Orman Bakanlığı verileri kullanılarak Sığır Tüberkülozu (bTB)'nun Türkiye'de son 16 yıldaki zamansal değişimi ile mekânsal örüntülerini ortaya çıkarmayı amaçlamaktadır. Hastalığın zoonotik karakteri ve sosyo-ekonomik etkisi düşünüldüğünde son zamanlarda bTB mihrak sayılarının hızlı artışı kaygı verici düzeylere erişmiştir. Nitekim 2005-2020 yılları arasında mihrak sayılarının yaklaşık 20 kat artışı bunu açıça göstermektedir. Aynı dönemde hastalık nedeniyle şarta tabi kesilen ve ölen 168.244 büyükbaş hayvan için yaklaşık 611 milyon yeni TL (も) tazminat ödemesi hastalığın ekonomik etkisini ortaya koymaktadır. Ayrıca, insan vakalarının düşük bir oranda $(\% 5,3)$ olsa da M. bovis kaynaklı olduğu bilinmektedir. bTB mihrak sayılarının artışına paralel bir şekilde hastalık coğrafik olarak ülke geneline (bazı iller dışında) yayılmıştır. bTB hastalığıyla etkin mücadele edilebilmesi, halk sağlığına yönelik risklerin ve hastalığın neden olduğu sosyo-ekonomik kayıpların azaltılması önemlidir. Bu nedenle epidemiyolojik olarak hastalık mihraklarının zamansal seyrinin izlenmesi ve çeşitli ölçeklerde mekânsal örüntülerini ortaya çıkarmak son derece önem arz etmektedir. bTB ile etkin bir mücadele için, hastalığın epidemiyolojisindeki bulaşma dinamiklerine ait tüm değişkenlerin (özellikle hayvan hareketleri) zamansal değişimi ve mekânsal dağılım dinamiklerinin izlenmesi, analiz edilmesi ve uygulamaya geçirilmesi hayati önem taşımaktadır.
\end{abstract}

Anahtar kelimeler: Mekânsal dağılım, Mycobacterium bovis, sığır tüberkülozu, zamansal dağılım, zoonoz

\section{Introduction}

Bovine Tuberculosis (bTB) is an infectious disease of cattle caused by Mycobacterium bovis (M. bovis). It has a zoonotic character and a wide host range that can infect wildlife, causes remarkable economic losses such as yield losses, expenditures for the control of the disease, and international trade restrictions (Orloski et al. 2018; Raphaka et al. 2018; Mekonnen et al. 2019). bTB is a major cause of economic loss to livestock owners worldwide with an estimated over 50 million infected cattle and an annual cost of $\$ 3$ billion (Waters et al. 2012). The disease causes zoonotic tuberculosis in humans, especially as a result of unpasteurized milk consumption or living with infected animals. For the control and eradication of 
the disease, the test and slaughter method is applied by most countries (Buddle et al. 2018).

bTB is a chronic disease that has an endemic course in cattle herds in Turkey (Viviani et al. 2016). In a study conducted in different provinces with the Tuberculin Skin Test (TST) in 2000 to determine the prevalence of bTB, a positivity rate of $9.9 \%$ was found (Doğan 2011). Finally, in a national study conducted in 2011, the individual cattle prevalence was reported as $1.4 \%$ and the herd prevalence was approximately $2.5 \%$ with a comparative intradermal tuberculin test in 2011 (Bartels et al. 2012). The socio-economic impact of bTB on public health and the agricultural sector in Turkey is estimated to be between $\$ 15$ and $\$ 59$ million annually (Cousins 2001). According to the data of the Ministry of Agriculture and Forestry (MoAF), while 59 bTB outbreaks were reported in Turkey in 2001, the number of outbreaks showed an increasing trend in the following years and reached the highest level in the country's history with 2,248 bTB outbreaks in 2019 (Doğan 2011). This 38-fold increase in the number of bTB outbreaks will also be reflected an increase in public health risk and socio-economic loss. bTB should also be monitored because of being a zoonotic disease. As a matter of fact, according to the data of the Ministry of Health, the number of Tuberculosis patients in Turkey was reported as 11,821 in 2017 (Kara et al. 2020). When the strains isolated from these patients were evaluated, it was reported that $5.3 \%$ of them were caused by M. bovis (Bayraktar et al. 2011).

With this study, it was aimed to monitor the temporal course of bTB outbreaks in Turkey and to determine their spread with spatial patterns according to the World Animal Health Organization, Animal Health Information System (OIE, WAHIS), and MoAF data. Changes in temporal increase trends and spatial patterns of bTB outbreaks can provide meaningful information in terms of determining strategies in combating the disease.

\section{Material and Method}

In this descriptive study, the data on bTB outbreaks of Turkey in annual animal health reports from OIE, WAHIS between 2005 and 2020, and the number of animals and compensation paid for the same period due to bTB disease obtained from the General Directorate of Food and Control (GDFC) of MoAF were used. These reports were transferred to Microsoft office programs and epidemiological analyzes of the temporal course and spatial diffusion patterns of bTB outbreaks by years, provinces, and months were done retrospectively. In addition, the literature was searched and the information about the number of outbreaks of previous years and the studies carried out in the fight against the disease were included in our research.

Since the subject of this research is a notifiable disease, necessary legal permissions have been obtained from MoAF to provide the data and publish the results.

\section{Results}

\section{Temporal changes of bovine tuberculosis outbreaks (2005-2020)}

According to the veterinary statistics published by the MoAF on the notifiable animal diseases, 31 bTB outbreaks between 1976-1978 and 45 bTB outbreaks between 1980-1985 were reported (Doğan 2011). In 1985, the "Turkey Tuberculosis Struggle Project" was prepared. Turkey was divided into five regions, starting from the $1^{\text {st }}$ region, $20 \%$ of the animal population in the first year and $40 \%$ in the second and third years were included in the scope of the struggle. Within the scope of the project, it was aimed to carry out the struggle in 67 provinces, 639 districts, and 36,610 villages and to apply TST to a total of $5,851,000$ animals. TST was applied to 249,387 cattle in 1986 , and a total of 1,983 $(0.79 \%)$ cattle were found to be bTB positive in 153 outbreaks. TST was applied to 63,920 cattle in 1987 and a total of $252(0.39 \%)$ cattle were found to be bTB positive in 96 outbreaks. TST was applied to 117,500 cattle between 1988 and 1995, and a total of $1,474(1.25 \%)$ cattle were determined to be bTB positive in 263 outbreaks. Although we do not have data for 1996 and 1997, when the average between 1996 and 2004 is evaluated, it is understood that TST was applied to approximately 40,000 cattle and bTB outbreaks between 470-500 was observed (Sayın 2010; Doğan 2011). According to these data, it can be said that between 1976 and 2004, approximately 1,050-1,100 bTB outbreaks were detected in Turkey. In a study carried out by the Veterinary Control Central Research Directorate in 2000 to determine the prevalence of bTB in Turkey as an indicator between these years, positivity was found in $522(9.9 \%)$ animals that were administered TST to 5,257 animals from different (Doğan 2011).

According to OIE-WAHIS data, the number of bTB outbreaks in Turkey between 2005 and 2020 can 
be categorized as $1^{\text {st }}$ period $(2005-2010), 2^{\text {nd }}$ period (2010-2016), and $3^{\text {rd }}$ period (2016 and after) as seen in Figure 1. In these three periods, first there was an increase and then a decrease as a general trend. This course shows us that the slaughter of reactor animals as a result of the combat efforts is reflected in the decrease of the outbreaks numbers in the following years. The number of outbreaks in 2012 exceeded an important threshold by triple the number of outbreaks of the previous year. With 2,248 outbreaks in 2019, the annual number of bTB outbreaks reached the highest known level in the history of our country. Between 2005 and 2020, there was an approximately 20 -fold increase in the number of bTB outbreaks.

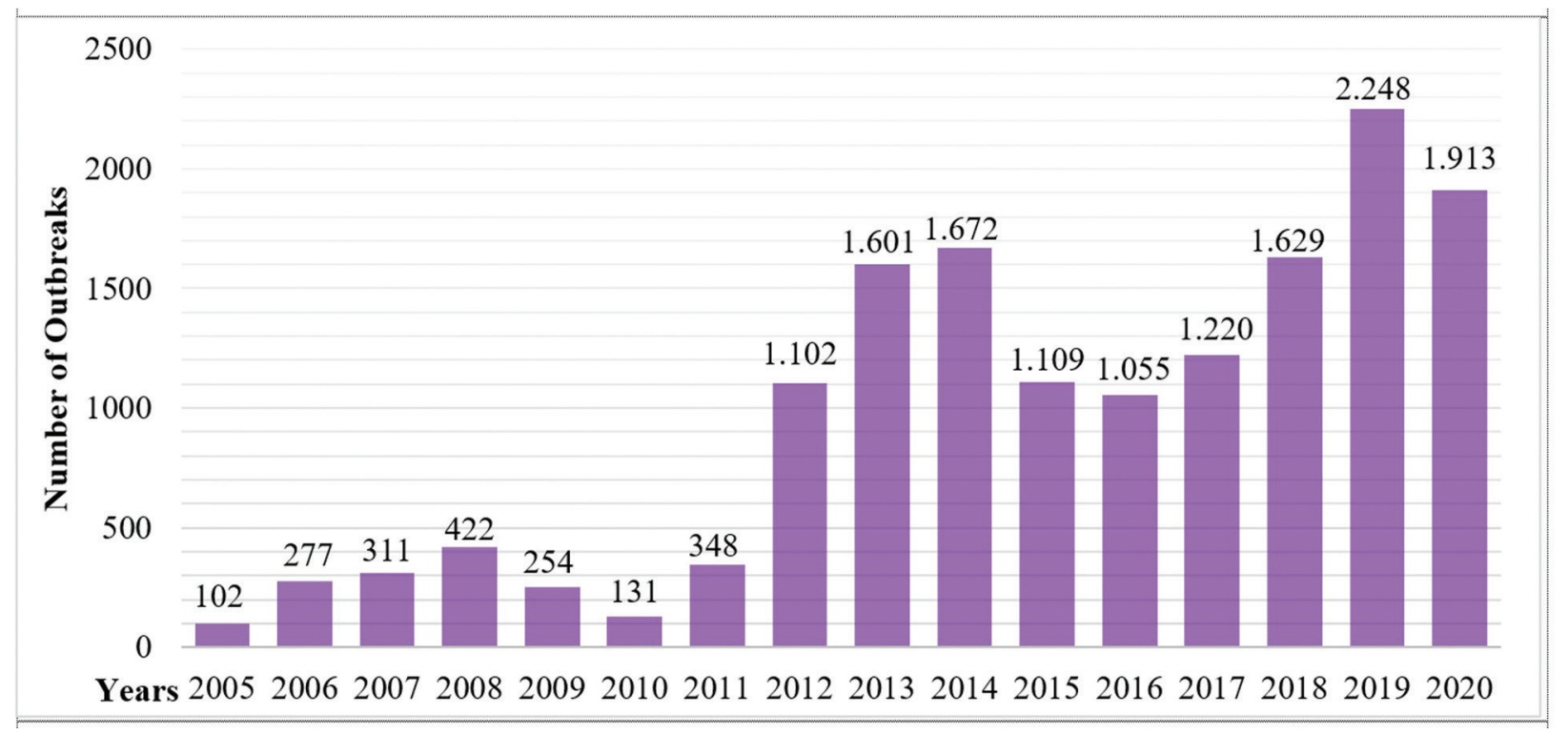

Figure 1. Distribution of bTB outbreak numbers in Turkey (2005-2020) (OIE-WAHIS)

\section{Distribution of bovine tuberculosis outbreaks by months (2005-2020)}

Epidemiological processes of infectious diseases need to be monitored at different temporal scales. In this context, the purpose of examining the distribution of bTB outbreaks based on the current data in Turkey according to the months in the year, apart from the annual course is to consider latent course of the disease, animal movements between the premises during the year, the animals being in the barns or pasture, sacrificial slaughter, the time of compensation payment, the increase or decrease in the slaughters due to the change in meat consumption during the year, which may be effective in the reporting of bTB suspected cases. All these predicted factors require monitoring and examining not only the annual but also the monthly course of the disease outbreak numbers.

The general increase in the monthly course of bTB outbreaks between 2005 and 2020 is shown in Figures 2-3. When the distribution of the outbreaks by months is carefully examined, it is notable that there is a significant increase of outbreak numbers in September 2016-2017, and in August 2018-20192020 , although there is no obvious seasonality. This increasing trend in the monthly distribution and the monthly shift towards the previous month over the years should be related to the fact that the Feast of Sacrifice coincides with these months in the mentioned years. As a reflection of the increasing prevalence of the disease, the possibility of macroscopic lesions in sacrificial cattle has also increased. It is considered that there is an increase in the number of outbreaks due to the notifications made as a result of the presence of disease lesions during sacrificial slaughter. This situation gives the impression that within the scope of the relevant compensation regulations, 3/4 of the value of their carcasses will be compensated for the cattle slaughtered in slaughterhouses or designated sacrificial slaughtering places during the Feast of Sacrifice, and based on these notifications the disease is diagnosed as a result of TST applied in the origin premises. 


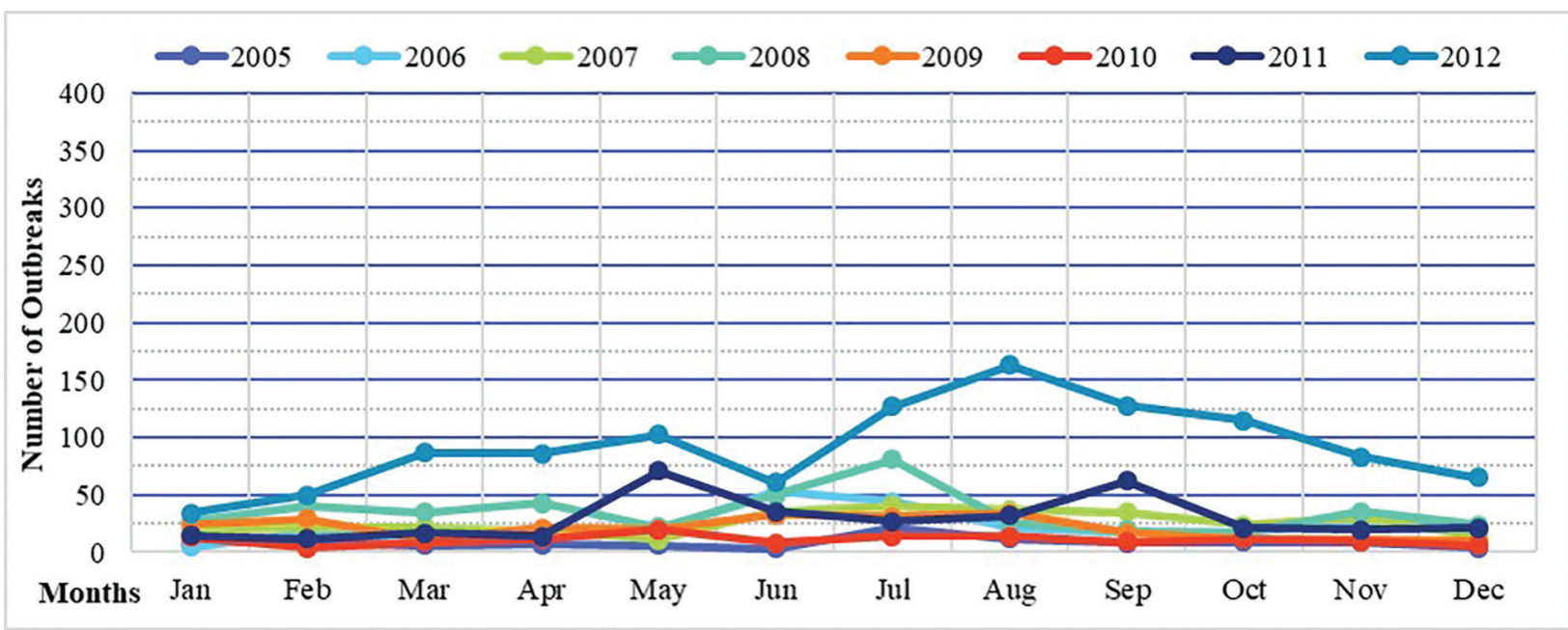

Figure 2. Monthly distribution of bTB outbreaks in Turkey (2005-2012) (OIE-WAHIS)

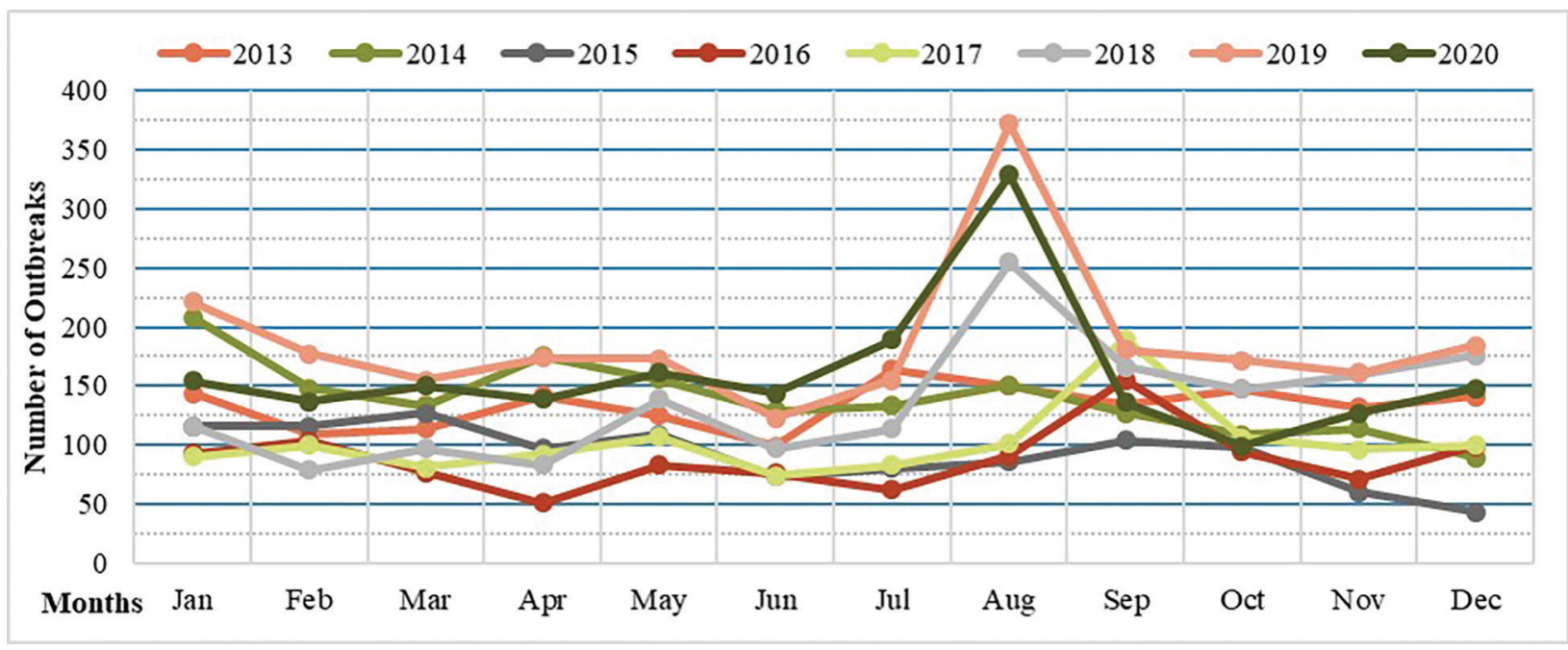

Figure 3. Monthly distribution of bTB outbreaks in Turkey (2013-2020) (OIE-WAHIS)

\section{Temporal changes of the number of animals compensated and the amount of compensation paid (2005-2020)}

The provisions regarding the culling and compensation of the bTB (tederrün-The Ottoman Turkish name of bTB in Legislations) were included for the first time in the Law named "Zâbıta-i Sıhhiye-i Hayvâniye Kânun-i Muvakkatî" adopted on 18 December 1913 to combat animal diseases. In this Law, it is stipulated that in case of culling of animals with positive results in tuberculin application, 1/2 of the value of the animal, and in case of culling of suspicious animals, 2/3 of the price will be paid as compensation (Doğan 2011). After various adjustments were made in the legislation in the intervening pe- riod, compensation is paid according to the provisions of the "Veterinary Services Plant Health Food and Feed Law" numbered 5996 published in the Official Gazette on 13 June 2010 and the compensation regulations published within the scope of this Law. Accordingly, compensation is paid at the rate of $9 / 10$ of their appreciated value for cattle determined with TST or killed or slaughtered during the quarantine period, and 3/4 of their carcass value for cattle detected as bTB as a result of slaughter in the slaughterhouse or in the sacrificial slaughter places.

The general sum of the loss aimed to be prevented by the project planned to combat bTB in 1985 was calculated as $201,162,537,000 \mathrm{TL}$, according to the former TL. In 1986 which was the first year of 
the project $211,973,852$ TL compensation was paid for 1,983 cattle. However, financial problems were encountered in the following years and 50,177,282 TL compensation was able to be paid for 252 cattle in 1987. Between 2000 and 2004, a compensation of 1,109,948,472 TL was paid for 1,361 cattle, according to the total former TL (Doğan 2011).

Between 2005 and 2020, a compensation of $610,907,224$ € was paid for 168,244 cattle according to the new TL ( () . The number of compensated animals and the amount of compensation paid in this period are shown in Figure 4. In parallel with the periodic increase or decrease in the number of bTB outbreaks, an increase or decrease is observed in the number of animals for which compensation is paid and the amount of compensation paid. It is seen that the deductions made according to the age, gender, general valuation of the animals for which compensation is paid; the price of roasting paid, and the increase in the animal prices are also reflected in the amount of compensation. For instance, although the numbers of animals that were conditionally slaughtered or died due to bTB positivity in 2013 and 2019 were similar, according to the data of the Turkish Statistical Institute, there was an about twofold increase in the amount of compensation paid due to the increase in livestock prices between these years. In addition, starting the deduction of the depreciation value of these animals over the value of them in accordance with the legislation in these years was reflected as a decrease in the amount of paid compensation.

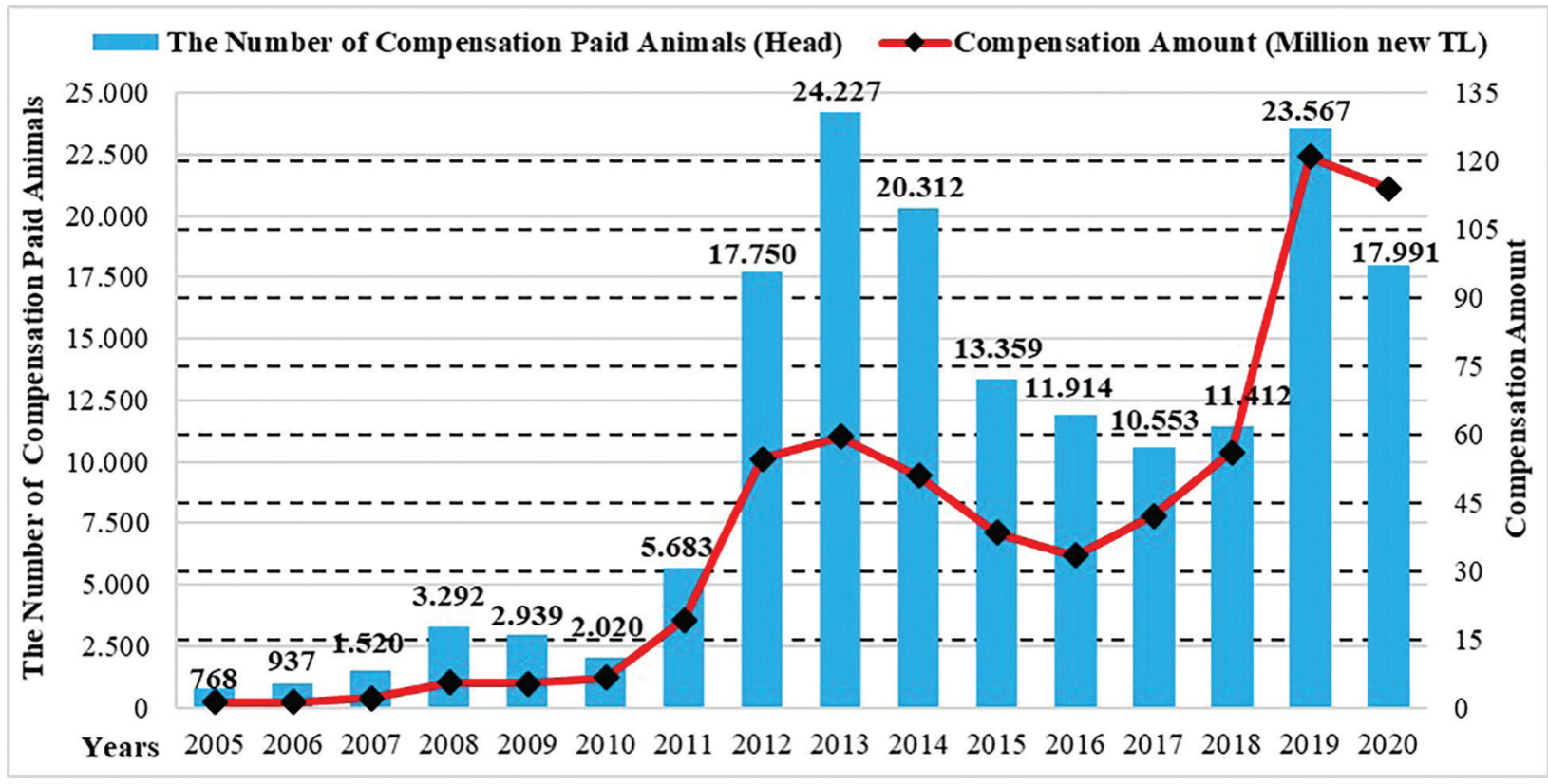

Figure 4. The number of animals for which compensation was paid due to bTB disease in Turkey and the amount of compensation (2005-2020) (MoAF) (\$1=Approximately 9.5 new Turkish Lira)

\section{Spatial distribution of bovine tuberculosis outbreaks by provinces (2005-2020)}

In addition to the general course of bTB disease in the country, its spatial distribution should also be monitored. At least $45.1 \%$ of bTB disease outbreaks are in other premises in the same settlement and its spread shows spatially different patterns (Çakır 2021). In this study, the data obtained from the OIE-WAHIS database and organized according to the provinces were mapped separately per years, and the total numbers between 2005 and 2020 were mapped thematically (choropleth). When the maps are examined, it is understood that bTB disease has spread over time to all provinces in Turkey, except for some provinces of the Eastern Black Sea, Eastern and Southeastern Anatolia regions (Figures 5-9). 


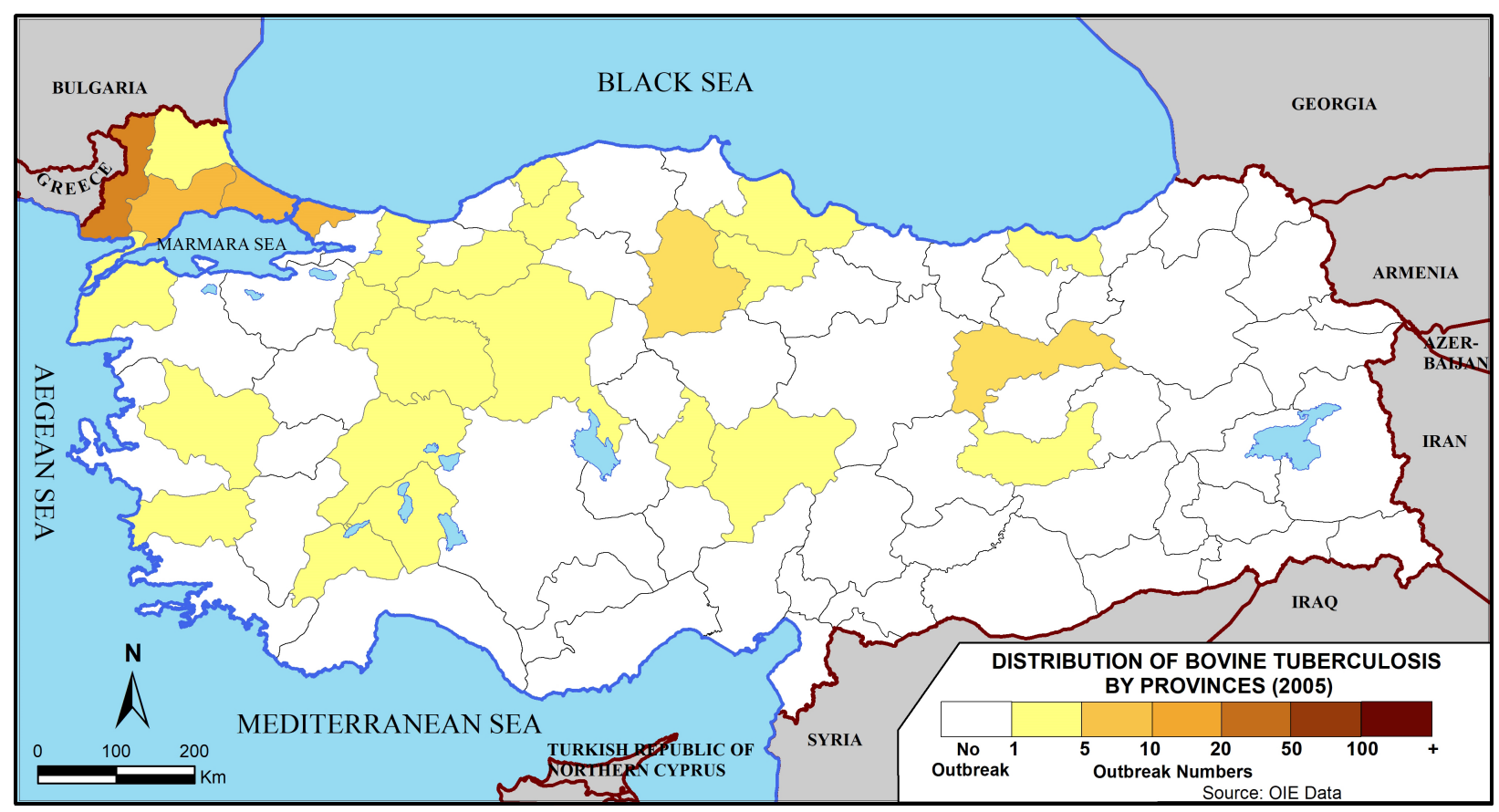

Figure 5. Distribution of bTB outbreaks by provinces in Turkey (2005) (OIE-WAHIS)

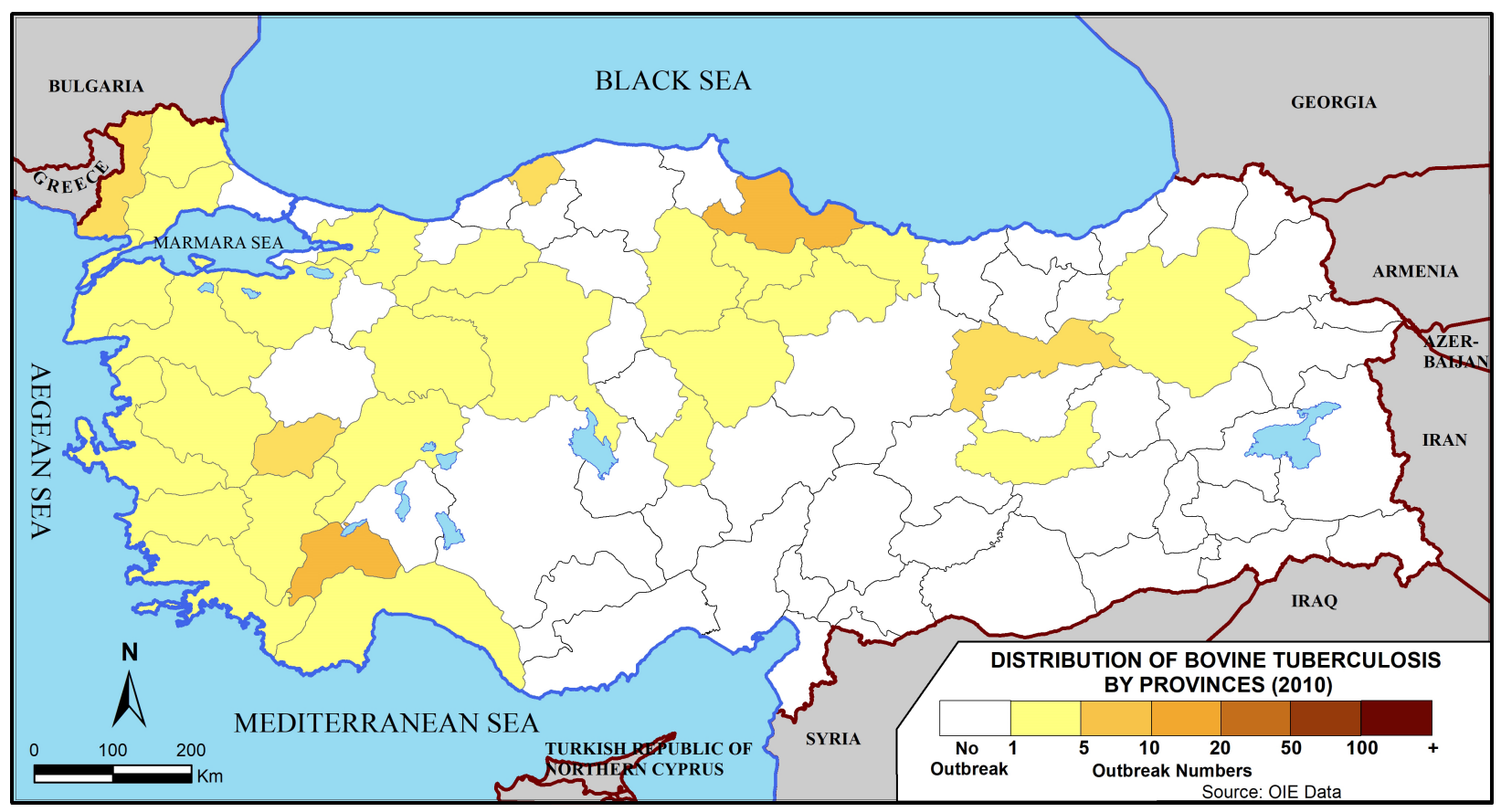

Figure 6. Distribution of bTB outbreaks by provinces in Turkey (2010) (OIE-WAHIS)

The fact that the disease is less common in the Eastern Black Sea region may be related to the geographical structure of the region and the small scale and scattered premises. In some provinces in the Eastern and Southeastern Anatolia regions, it can be thought that the disease notifications may not have been made sufficiently. In the provinces with a high outbreak density, it has been considered that postmortem inspection is carried out effectively in slaughterhouses and the disease notification is made carefully as a result of the application of TST to the animals in the suspicious premises by providing the 
feedback of the detected cases. The change in the distribution of both the annual and the total number of outbreaks between 2005 and 2020 by provinces is remarkable. For sure, it is necessary to focus on the change in the size of the total number of cattle in the provinces and the differentiation of the premise typology.

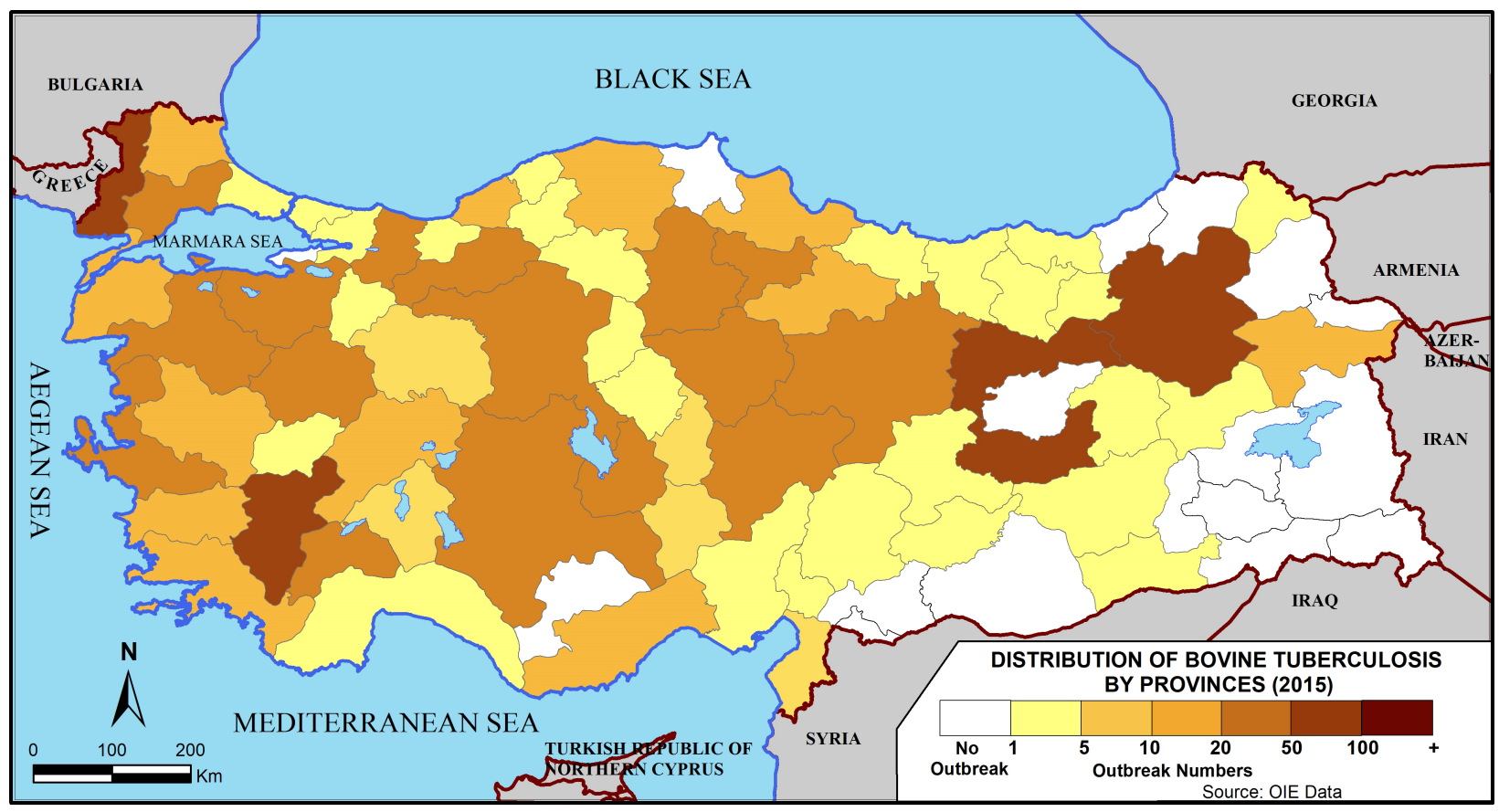

Figure 7. Distribution of bTB outbreaks by provinces in Turkey (2015) (OIE-WAHIS)

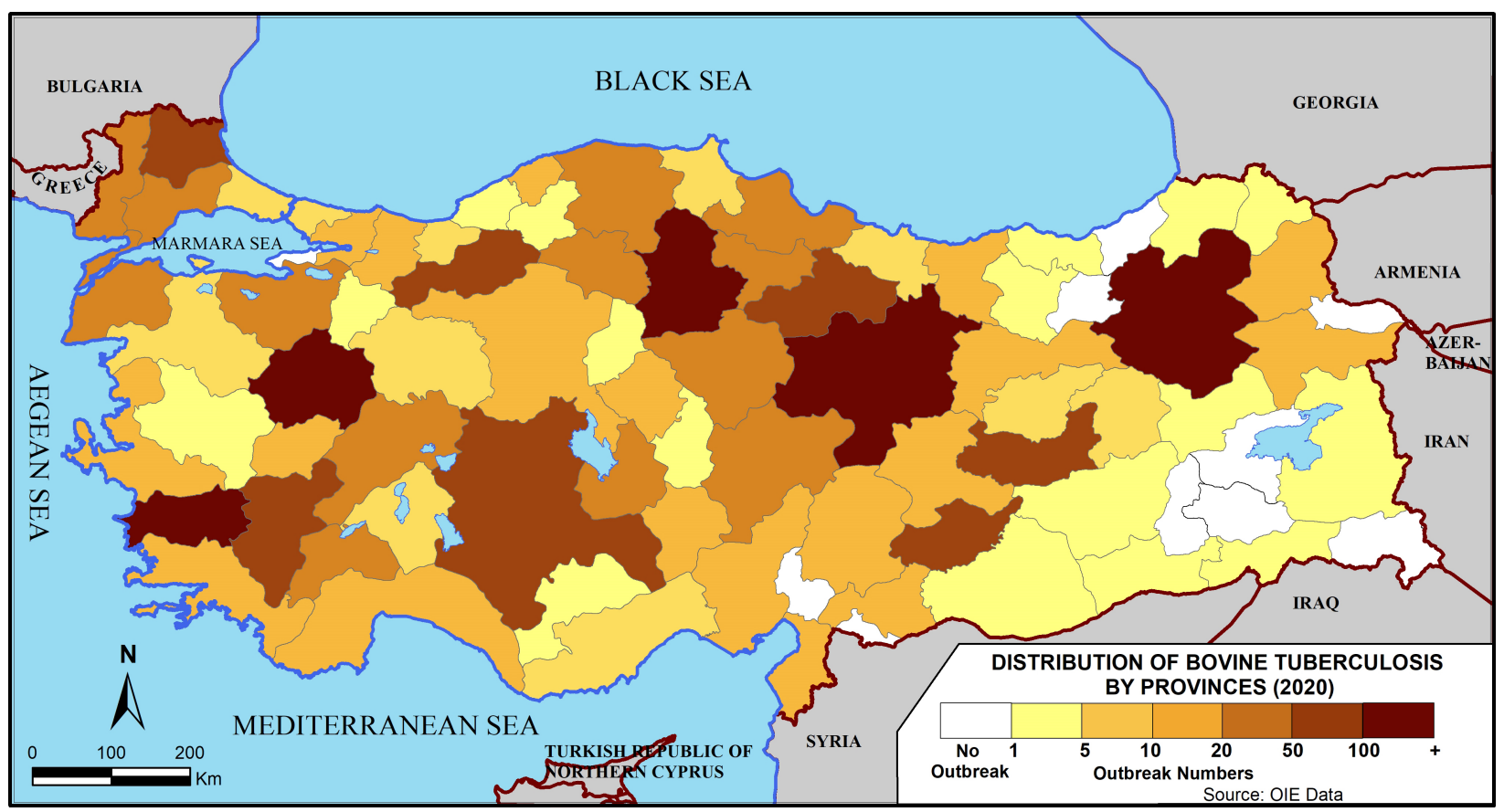

Figure 8. Distribution of bTB outbreaks by provinces in Turkey (2020) (OIE-WAHIS) 


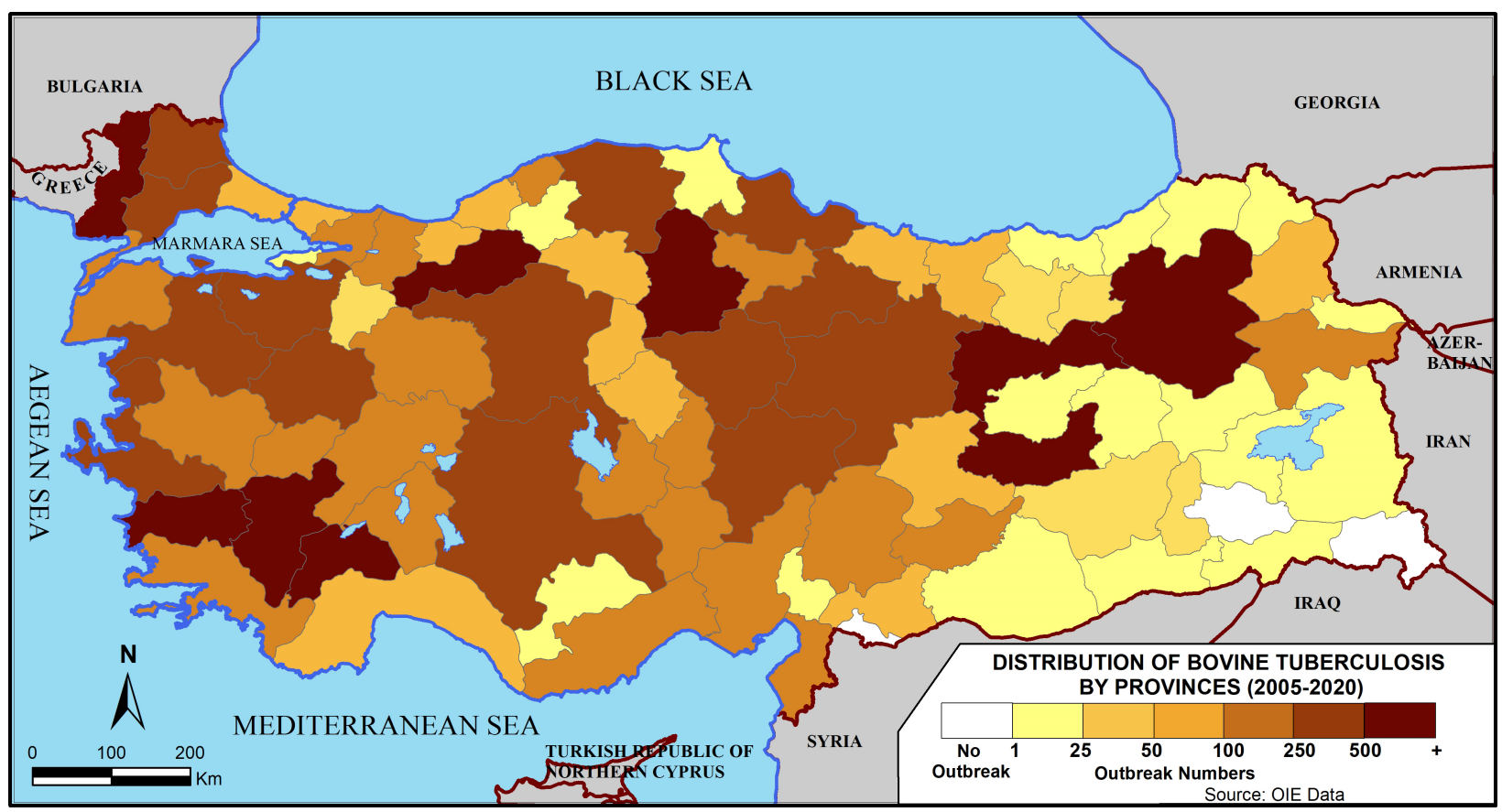

Figure 9. Total distribution of bTB outbreaks by provinces in Turkey (2005-2020) (OIE-WAHIS)

The first 10 provinces with the highest number of bTB outbreaks in total between 2005 and 2020 and the number of outbreaks are shown in Figure 10. It is seen that provinces such as Denizli, Erzincan, Erzurum, and Aydın always have more outbreaks. It can be said that the disease has spread more in these provinces or an effective struggle is carried out within the scope of combating the disease compared to other provinces.

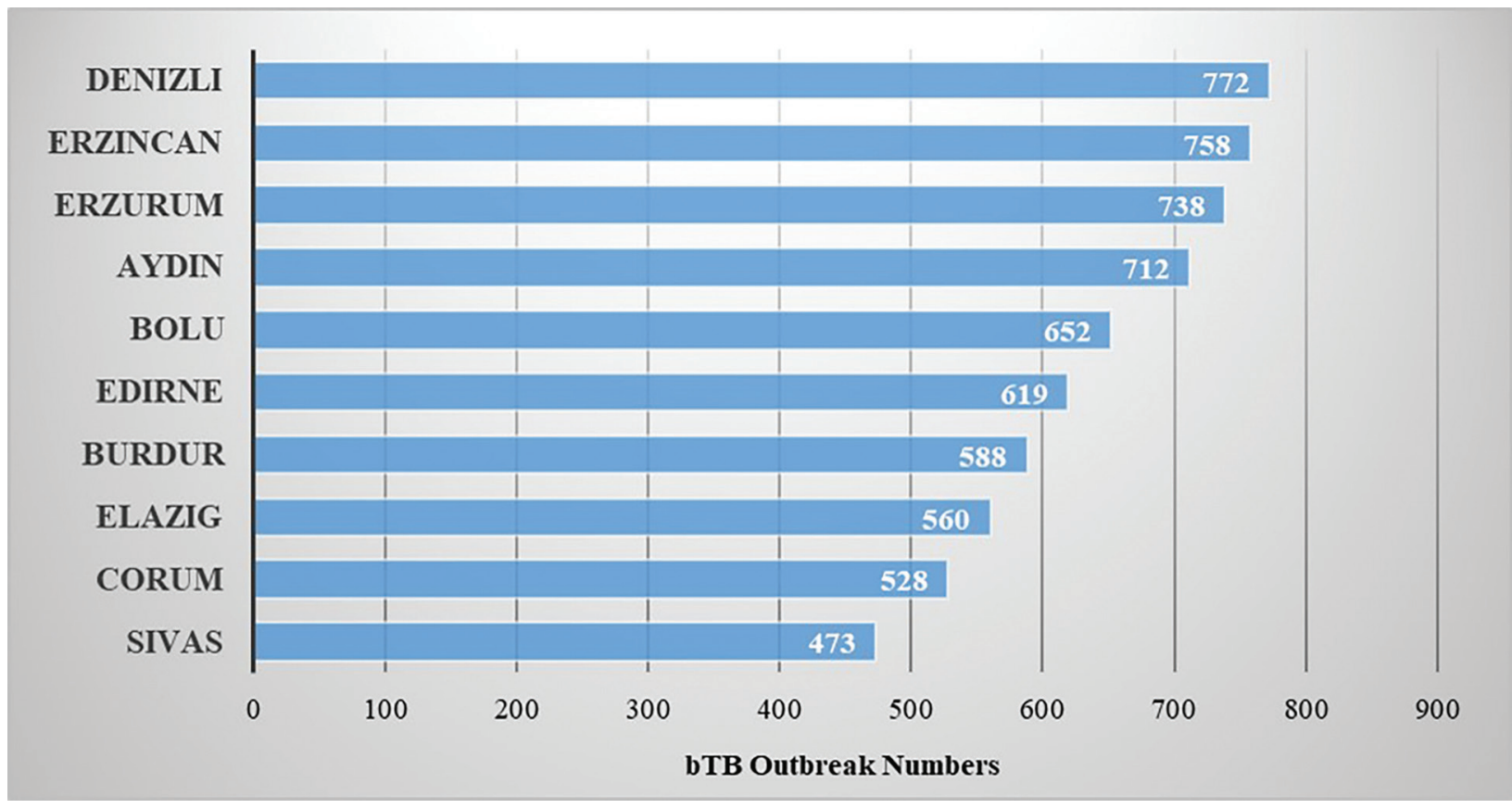

Figure 10. Ten provinces with the most bTB outbreaks in Turkey and the number of outbreaks (2005-2020) (OIE-WAHIS) 
The spatial aspects and frequencies of animal movements also determine the spatial distribution patterns of the disease. Several factors can be mentioned in the emergence of different patterns of spatial distribution. The spatial distribution patterns of these factors according to the provinces can also be mapped and associated with the spread of the disease. Apart from this, knowing and monitoring spatial patterns in the fight against the disease will be useful for the development of control strategies. The spatial scale of the data on the epidemiology of the disease and the dynamics affecting it also needs to be carefully considered. Mapping can also be done according to regions, provinces, districts, villages, and even premises. When we change the spatial scale of the map, the emerging patterns will differ and the priority areas of intervention will be clearly defined. Quarantine measures to be applied to these areas when necessary are of vital importance in preventing the spread (diffusion) of the disease. Here, the spatial perspective will make a meaningful contribution with all these aspects of the course of the disease and the results it will reveal.

\section{Discussion and Conclusion}

bTB disease in cattle has inherent difficulties such as its latent course, easy transmission, lacking sensitivity and specificity of diagnostic tests, the fact that an effective vaccine that provides enough immunity and does not interfere with diagnostic tests has not been developed so far, and its struggle is long-term. In addition to all these, the existence of causes such as Turkey's unique family-type premise structure, insufficient control of animal movements, animal markets, dealers, pasture livestock, social projects, economic situation, etc. accelerates the spread of bTB disease among premises. The total number of bTB outbreaks between 1976 and 2004 started to occur annually after 2012. In 2012, it tripled the number of the previous year and exceeded an important threshold. Between 2005 and 2020, the number of outbreaks increased approximately 20 times and reached the highest value in the country's history in 2019.

The increase in the number of bTB outbreaks in Turkey, especially in recent years, makes it difficult to fight against the disease effectively. At the same time, it causes an increase in risks to public health and an increase in multi-drug resistant $M$. bovis strains in the treatment process of humans. The incidence of the disease is also increasing in humans whose immune system is suppressed ( $\mathrm{HIV}+$ ).

The fight against the disease brings a serious socio-economic burden to the country in the long term. It is extremely important that it causes an increase in socio-economic losses such as yield and breeding animal losses, struggle costs, paid compensations, treatment costs of humans, trade restrictions due to the disease.

It is seen that the payment of compensation due to the detection of bTB lesions in animals slaughtered in slaughterhouses and designated sacrificial slaughtering places during the Feast of Sacrifice is reflected in the disease notification figures. As a result of the questionnaire study we conducted within the scope of the national project, it was seen that the failure to pay the compensations on time negatively affected the decision of $24 \%$ of the breeders (Çakır 2021). To fight the disease effectively, it is important that compensation payments are paid on time, without any deductions, and by providing a sustainable source of finance. Otherwise, breeders and slaughterhouses do not act sensitively in the notification of the disease, causing the disease to spread more and putting public health at more risk. Since there has not been any research on the epidemiology of bTB in Turkey until today, no comparison has been made on a national scale. To conduct a more detailed epidemiological study on the dynamics of bTB infection, the direction and magnitude of animal movements and the Geographic Information System coordinate data of premises with bTB outbreaks are needed. Apart from this, the possibility of transmission with wildlife contact should be considered.

Conflict of interest: The authors declare no conflict of interest.

Acknowledgment: A part of this study is based on the doctoral thesis "Developing an epidemiological model based on the infection dynamics of Bovine Tuberculosis" at Kırıkkale University Health Sciences Institute. We thank the Veterinary Control Central Research Institute personnel for their contribution to the project. This study was supported as a national project (TAGEM/HSGYAD/Ü/20/A5/ P1/1643) by MoAF, General Directorate of Agricultural Research and Policies.

Ethical Statement: Ethics committee approval is not required for this study.

\section{References}

Bartels C, Bergevoet R, Emmerzaal A, Emmerzaal A, De Gee T, Schrijver R, Van Zijderveld F. (2012) Türkiye'de bruselloz ve tüberkülozun eradikasyonu. Central Veterinary Institute, Wageningen, Netherlands.

Bayraktar B, Bulut E, Barış AB, Toksoy B, Dalgıc N, Çelikan C, Sevgi D. (2011) Species distribution of the Mycobacterium 
tuberculosis complex in clinical isolates from 2007 to 2010 in Turkey: A prospective study. J Clin Microbiol. 49, 3837-3841. doi:10.1128/JCM.01172-11

Buddle BM, Vordermeier HM, Chambers MA, de Klerk-Lorist L-M (2018) Efficacy and safety of BCG vaccine for control of tuberculosis in domestic livestock and wildlife. Front Vet Sci. 5, 259. doi: 10.3389/fvets. 2018.00259

Cousins DV. (2001) Mycobacterium bovis infection and control in domestic livestock. Rev Sci Tech. 20, 71-85.

Çakır Ş. (2021) Sığır tüberkülozunun enfeksiyon dinamiklerine dayalı epidemiyolojik model geliştirme. Doktora Tezi. Kırıkkale Üniversitesi Sağlık Bilimleri Enstitüsü, Kırıkkale.

Doğan Ö. (2011) Türkiye'de sığır tüberkülozunun kontrolü ve eradikasyonuna yönelik çalışmaların tarihi. Doktora Tezi. Fırat Üniversitesi Sağlık Bilimleri Enstitüsü, Elazığ.

Kara F, Kabasakal E, Yıldırım A, Mutlu MS, Baykal F. (2020) Türkiye'de Verem Savaşı 2019 Raporu. Sağlık Bakanlığı, Ankara.

Mekonnen GA, Conlan AJK, Berg S, Ayele BT, Alemu A, Guta S, Lakew M, Tadesse B, Gebre S, Wood JLN, Ameni G, The ETHICOBOTS consortium (2019) Prevalence of bovine tuberculosis and its associated risk factors in the emerging dairy belts of regional cities in Ethiopia. Prev Vet Med. 168, 81-89. doi: 10.1016/j.prevetmed.2019.04.010
Orloski K, Robbe-Austerman S, Stuber T, Hench B, Schoenbaum M (2018) Whole genome sequencing of Mycobacterium bovis isolated from livestock in the United States, 1989-2018. Front Vet Sci. 5, 1-10. doi: 10.3389/fvets.2018.00253

Raphaka K, Sánchez-Molano E, Tsairidou S, Anacleto O, Glass EJ, Woolliams JA, Doeschl-Wilson A, Banos G. (2018) Impact of genetic selection for increased cattle resistance to bovine tuberculosis on disease transmission dynamics. Front Vet Sci. 5, 1-14. doi:10.3389/fvets.2018.00237

Sayın Z. (2010) Sığır tüberkülozunun farklı metotlar ile karşılaştırmalı teşhisi. Doktora Tezi. Selçuk Üniversitesi Sağlık Bilimleri Enstitüsü, Konya.

Viviani P, Tufan M, Kirandjiski T, Ediz B, Çağatay M, Aktaş S, Nazzarri N, Bozkurt Z, Özgenç Y, Kılınç B, Göral A, Özkan D, Agah H, Tizzani P, Diker KS, Akan M, Yılmaz H, Aydın L, Hasöksüz M, Altun S, Sensi M, Petrini S, Magistrali C, Karslıoğlu N, Budak N, Karakoyunlu I, Coşgun E. (2016) Veteriner Hizmetleri Strateji Belgesi Nihai Raporu. Avrupa Birliği (Agrotec SPA) ve Tarım ve Orman Bakanlığı.

Waters WR, Palmer MV, Buddle BM, Vordermeier HM. (2012) Bovine tuberculosis vaccine research: Historical perspectives and recent advances. Vaccine. 30, 2611-2622. doi:10.1016/j. vaccine.2012.02.018 